\title{
SUCCESSFUL TREATMENT OF ACUTE DISSEMINATED ENCEPHALOMYELITIS (ADEM) BY PROMPT USAGE OF IMMUNOGLOBULINS - CASE REPORT AND REVIEW OF THE LITERATURE
}

\author{
Ana Repić-Buličić, Petar Filipović-Grčić, Eni Jadrijević, Pavao Jurinović and Marina Titlić \\ Department of Neurology, Split University Hospital Centre, Split, Croatia
}

\begin{abstract}
SUMMARY - Acute disseminated encephalomyelitis (ADEM) is an inflammatory demyelinating disease of the central nervous system that usually affects children and young adults. It most commonly has a monophasic course, although relapses are reported. Clinical presentation of the disease includes encephalopathy and multifocal neurological deficits. There are no established reliable criteria for diagnosis of ADEM and sometimes it is difficult to distinguish it from first attack of multiple sclerosis, especially in adults. The diagnosis of ADEM is based on clinical, radiological and laboratory findings. In the treatment of ADEM, high doses of corticosteroids, plasmapheresis and immunoglobulins are used. We report a case of a young adult female patient with ADEM who fully recovered after prompt administration of high dose methylprednisolone and immunoglobulins.
\end{abstract}

Key words: Encephalomyelitis, acute disseminated; Immunoglobulins; Adrenal cortex hormones; Methylprednisolone; Case reports

\section{Introduction}

Acute disseminated encephalomyelitis (ADEM) is an immune-mediated, inflammatory, demyelinating disease that predominantly affects the white matter of the brain and spinal cord. The disease manifests as acute encephalopathy associated with multifocal neurological deficits ${ }^{1-3}$. Although it can occur at any age, ADEM is most common in childhood and young adulthood. It most commonly affects children between fifth and eighth year of life ${ }^{4-6}$. The disease usually has a monophasic course, although it can manifest by multiple relapses ${ }^{7}$. ADEM usually occurs several days to several weeks after a viral infection, although the cases after bacterial infection are reported ${ }^{8}$. Clinical presentation of ADEM may resemble other demyelinating

Correspondence to: Eni Jadrijevic, $M D$, Department of Neurology, Split University Hospital Centre, Spinčićeva 1, HR-21000 Split, Croatia

E-mail: eni.jadrijevic@gmail.com

Received August 17, 2015, accepted March 16, 2016 diseases such as a multiple sclerosis (MS), neuromyelitis optica (NMO) and transverse myelitis (TM). Reliable diagnostic criteria for distinguishing these diseases have not been established yet.

In patients with ADEM, magnetic resonance imaging (MRI) of the brain shows hyperintense lesions on fluid-attenuated inversion recovery (FLAIR) and T2-weighted MRI, and has an important role in diagnosing the disease ${ }^{9,10}$.

In the treatment of ADEM high doses of corticosteroids, plasmapheresis and immunoglobulins are used $^{11,12}$.

We report a case of an adult female patient with ADEM who fully recovered after prompt administration of methylprednisolone and intravenous immunoglobulins (IVIG).

\section{Case Report}

A 30-year-old female patient was admitted to the hospital with a diffuse headache accompanied by nausea, diplopia and instability while walking. She had no 

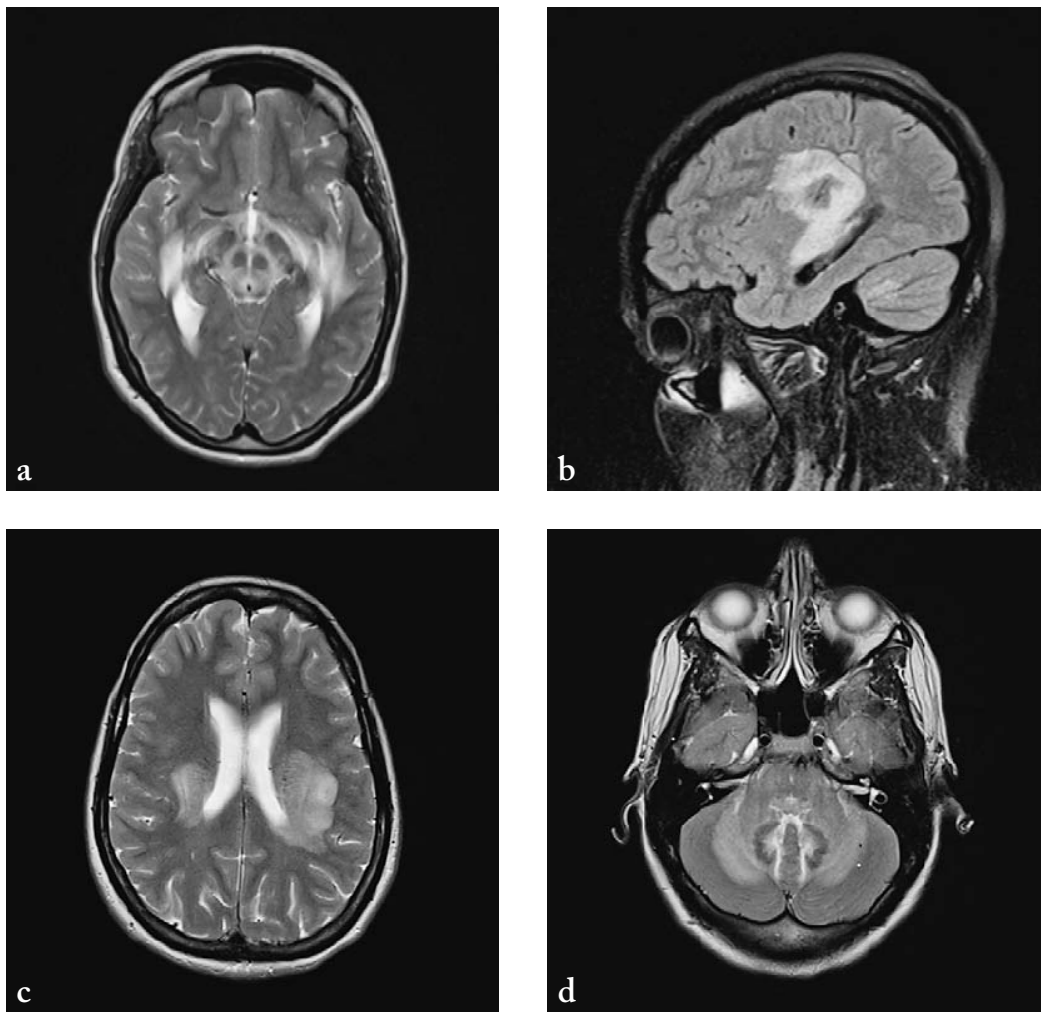

Fig. 1. MRI of the brain showing hyperintense lesions on T2-weighted sequences $(a-c)$ and FLAIR (d) on both sides of the cerebellum, in the medulla oblongata, pons and mesencephalon, on both sides of the posterior limb of internal capsule, in the thalamus, as well as in subcortical frontotemporoparietal white matter bilaterally and in the area of optic radiation.

past medical history. A week before admission, she had a cough occasionally, without fever. In neurological status, a lag of the left eye on upward gaze, right abducens paresis, horizontal nystagmus on vertical gaze, vertical nystagmus on upward gaze, and diplopia in all directions of gaze, as well as truncal ataxia were observed. Soon she became somnolent with psychomotor agitation, followed by spontaneous extensional cramps. On admission, computed tomography (CT) of the brain was normal. Analysis of the cerebrospinal fluid (CSF) showed pleocytosis (316/ $\mu \mathrm{L}$; normal 0-5 cells/ $\mu \mathrm{L})$, increased lactate levels $(4.3 \mathrm{mmol} / \mathrm{L}$; normal $1.1-$ $2.4 \mathrm{mmol} / \mathrm{L}$ ) and increased total protein content (1780.5 mg/L; normal 450/mg/L). Polymerase chain reaction (PCR) for herpes simplex virus (HSV) type I and II was negative, as well as oligoclonal bands. Serologic tests of CSF for neurotropic viruses and Borrelia burgdorferi were also negative. MRI of the brain showed multiple lesions of the white matter supratentorially and infratentorially in both hemispheres (Fig. 1). Urgently, two hours after admission to the hospital, methylprednisolone at a dose of $500 \mathrm{mg} /$ day intravenously was administered for five days, and then followed by oral methylprednisolone therapy in gradually lowering doses for four weeks. Also, IVIG at a dose of $0.4 \mathrm{~g} / \mathrm{kg}$ were administered for seven days. Acyclovir at a dose of $750 \mathrm{mg} 3$ times daily was administered on the first day only, until the results of PCR for HSV type I and II were obtained. At discharge, neurological status showed vertical nystagmus and mild dystaxia. MRI two weeks after the onset of clinical symptoms showed significant regression of changes described above (Fig. 2). Six weeks after the onset of symptoms, neurological status of the patient was normal, and so were MRI findings (Fig. 3). Somatosensory and visual evoked potentials were also normal. 

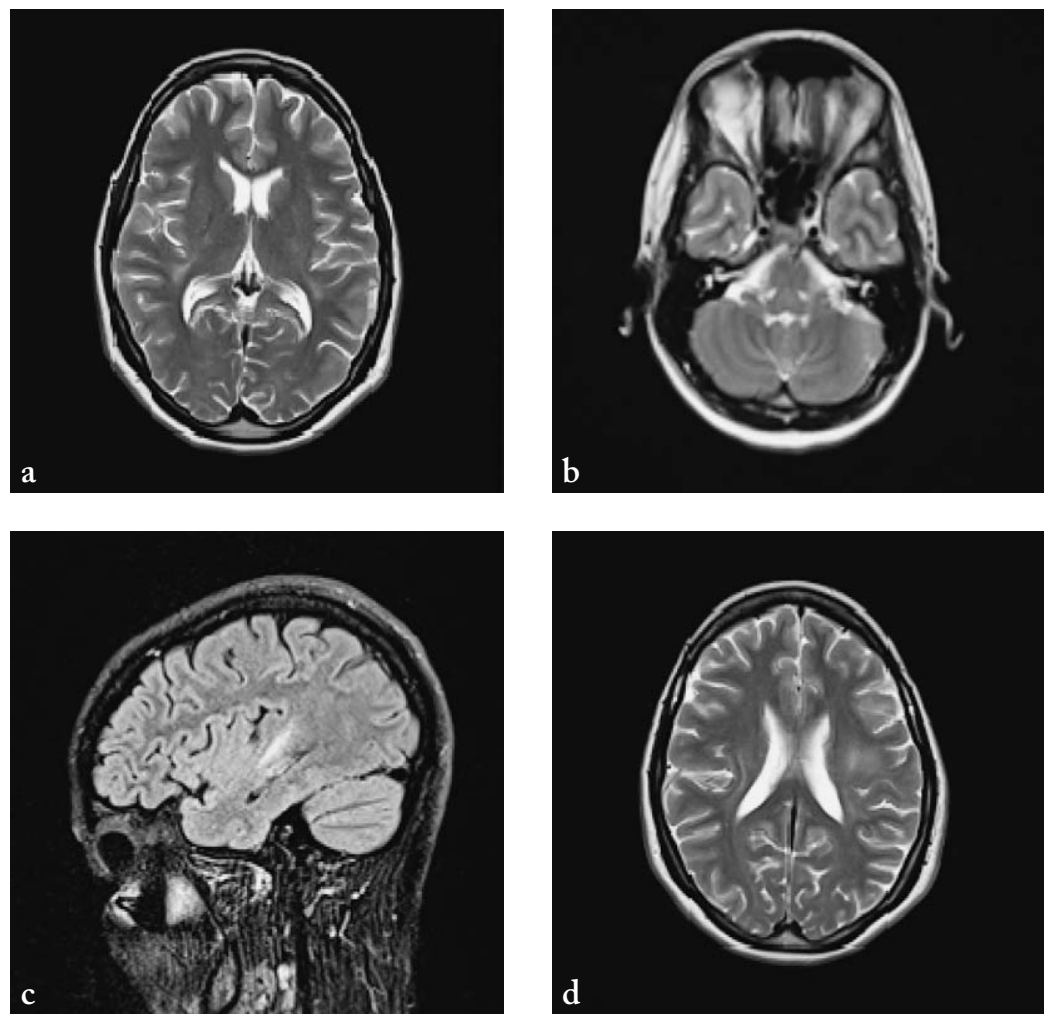

Fig. 2. MRI of the brain two weeks after first clinical presentation showing complete regression of earlier infratentorial lesions (a) and significant regression of supratentorial lesions $(b-d)$.
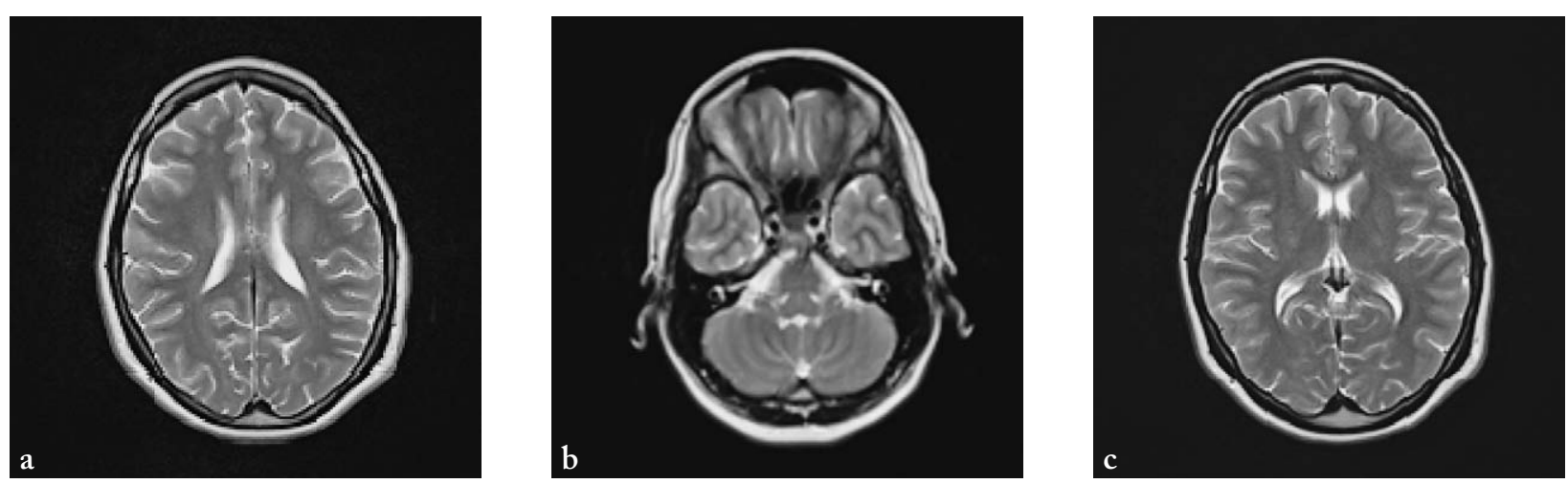

Fig. 3. (a-c) Normal MRI of the brain six weeks after first clinical presentation.

\section{Discussion}

Acute disseminated encephalomyelitis is an autoimmune encephalomyelitis with disseminated lesions of the white matter resulting from inflammatory demyelination ${ }^{2,13,14}$. The estimated incidence of ADEM is $0.8 / 100000 /$ year. Clinically, it is characterized by acute or subacute onset of multifocal neurological deficits that usually have a monophasic course $\mathrm{e}^{1,4,15,16}$. However, relapses are reported ${ }^{1,17,18}$, making distinguishing it from MS harder ${ }^{18-20}$.

Various combinations of motor, sensory, visual and cognitive symptoms may be part of a wide range of clinical manifestations of ADEM, but it usually begins 
with common symptoms such as fever, malaise, myalgia, headache and vomiting ${ }^{4,21}$. Movement disorders occur in $60 \%$, acute hemiplegia in $76 \%$, ataxia in $18 \%$ $65 \%$, cranial nerve palsy in $22 \%-45 \%$, vision loss in $23 \%$, convulsions in $13 \%-35 \%$, paraparesis and paraplegia in $24 \%$, speech disorders in $5 \%-21 \%$ of patients, while impairment of consciousness, from lethargy to coma, as well as respiratory failure have been reported in $11 \%-16 \%$ of cases ${ }^{4,9,22-24}$.

According to the results of previous studies, three categories of ADEM are differentiated: (1) monophasic ADEM, the first clinical event develops within three months, and any new or changing symptoms within this three-month period is considered as one event; (2) recurrent ADEM (RDEM) represents a new clinical event that occurs three months after the initial attack and involves the same symptoms and the same MRI findings that occurred during the initial attack; and (3) multiphasic ADEM refers to one or more relapses that involve new areas of the central nervous system (CNS) from the initial or previous attacks. Relapses occur at least three months after the initial $\mathrm{ADEM}^{25}$.

Acute disseminated encephalomyelitis and MS share a great deal of pathological and clinical similarities, but it is still unclear why some patients are affected by fulminant monophasic inflammatory process, whereas other patients suffer chronic polyphasic process $^{18}$. In both diseases, autoantibodies to specific myelin proteins and lipids contribute to the disease pathogenesis ${ }^{26-29}$. The seasonal distribution of ADEM, with the peak incidence in winter and spring, supports an etiological link with infectious disease ${ }^{4,18}$. An autoimmune attack on the CNS can be triggered by infection, and the possible mechanism is molecular mimicry $^{30}$. This process has an important role in MS too.

The histopathologic hallmark of ADEM is perivenular demyelination ${ }^{31-34}$, whereas MS is characterized by sharply limited, confluent demyelinated plaques $^{35}$. Some authors suggest that this histopathologic difference is the possible gold standard in diagnosing and distinguishing ADEM from $\mathrm{MS}^{21}$.

Magnetic resonance imaging has an important role in the diagnosis of acute CNS diseases affecting white matter. CT usually shows no abnormality in $\mathrm{ADEM}^{36,37}$. MRI often shows increased T2-weighted signal in multifocal areas in the CNS white matter, with or without involvement of gray matter. ADEM lesions are unclear and not sharply defined, unlike MS plaques, which have defined borders ${ }^{18,38}$. Overlap in lesion location and distribution between ADEM and MS was found in earlier studies, however, some features of ADEM that are unusual in MS were highlighted as well, such as relative sparing of the periventricular white matter or gray matter involvement ${ }^{39}$. For ADEM, absolute and relative sparing of the periventricular white matter on MRI is typical and is presented in $78 \%$ of patients. However, $22 \%$ of patients with ADEM have periventricular lesions indistinguishable from those seen in $\mathrm{MS}^{18}$. Tintore et al. compared MRI criteria to predict conversion to MS and found positive predictive value for increased number of lesions, infratentorial lesions and periventricular lesions ${ }^{40}$. According to some studies, corpus callosum long axis lesions, along with the finding of only well-defined lesions, were completely specific predictors of relapse and MS over a mean of 4.9 years. However, the difficulty of using initial MRI in identifying patients with an increased risk of relapsing disease and MS is highlighted by the fact that only $21 \%$ of patients presenting with the first episode of demyelination have this finding $^{38}$. Due to the relatively nonspecific findings, even when MRI seems typical of either ADEM or MS, a wide range of differential diagnosis of inflammatory demyelinating diseases needs to be carefully consid$\operatorname{ered}^{39}$. Therefore, in verifying the diagnosis of ADEM or suggesting alternative pathology, MRI criteria should be considered in combination with clinical criteria $^{21}$.

In both ADEM and the first presentation of MS, intrathecal synthesis of oligoclonal bands may occur. The absence of oligoclonal bands in CSF should be shown in convalescent testing in ADEM, while the oligoclonal bands may remain in $\mathrm{MS}^{23}$.

Some studies showed that these two diseases differ in immunoglobulin subtype ${ }^{28,29,41-45}$. Van Haren et al. found ADEM to be characterized by IgG autoantibodies targeting myelin basic protein, proteolipid protein, myelin-associated oligodendrocyte basic glycoprotein and alpha-B-crystallin, whereas MS was characterized by IgM autoantibodies targeting myelin basic protein, proteolipid protein, myelin-associated oligodendrocyte basic glycoprotein, and oligodendrocyte specific protein. These profiles of serum autoantibodies may be useful in distinguishing ADEM and MS, but further clinical studies have to confirm it ${ }^{46}$. 
Cerebrospinal fluid analysis must exclude infectious meningoencephalitis before diagnosing ADEM. Analysis of CSF in ADEM usually shows minor and unspecific changes. In some cases, it may reveal mild pleocytosis, with lymphocytes, monocytes and sometimes plasma cells, usually between 10 to 50 cells $/ \mu \mathrm{L}$, no more than $100 / \mu \mathrm{L}$. Total protein content is also increased but usually below $1000 \mathrm{mg} / \mathrm{L}^{47}$.

At present, there is no controlled trial concerning treatment of ADEM because of the low incidence of ADEM, therefore clinical data are the only basis for therapies for $\mathrm{ADEM}^{47}$. In some patients, spontaneous improvement has been reported ${ }^{48}$. Usage of high dose corticosteroids, IVIG and plasmapheresis is based on the analogy of the ADEM pathogenesis with that of MS $^{11,12}$. Therapy of ADEM usually starts with intravenous methylprednisolone at a dosage of $10-30 \mathrm{mg} / \mathrm{kg} /$ day for 3-5 days ${ }^{4,18,49-51}$. Full recovery has been reported in $50 \%-80 \%$ of patients with this modality of treatment. According to some studies, methylprednisolone treated patients had significantly better outcome when compared with those treated with dexametahasone ${ }^{52}$. In cases of insufficient response or contraindications to corticosteroids, IVIG at a dosage of $0.4 \mathrm{~g} / \mathrm{kg} /$ day for 5 days or $1 \mathrm{~g} / \mathrm{kg} / 2$ days are administered ${ }^{53}$. There are several cases in which full recovery following administration of IVIG have been reported. Assa et al. describe a case of two children with ADEM where full recovery occurred after IVIG administration at a dosage of $2 \mathrm{~g} /$ $\mathrm{kg}$ for five days ${ }^{54}$. Kleinmann and Brunquell describe an 11-year-old boy with ADEM who responded rapidly to the course of IVIG $^{55}$. A case of an 8-year-old boy with multiple episodes of disseminated demyelination of both hemispheres, cerebrum and brain stem who initially responded to corticosteroid therapy but developed exacerbations after cessation of treatment has been reported. He improved rapidly after administration of IVIG and no relapses are reported ${ }^{56}$.

In our case, prompt administration of high dose methylprednisolone and IVIG led to complete clinical and radiological recovery. Follow up MRI of the brain was scheduled at 6 months after discharge.

\section{References}

1. Rust RS. Multiple sclerosis, acute disseminated encephalomyelitis, and related conditions. Semin Pediatr Neurol. 2000;7(2): 66-90.
2. Tenembaum S, Chitnis T, Ness J, Hahn JS. Acute disseminated encephalomyelitis. Neurology. 2007;17;68 (Suppl 2):S23-S36. DOI: 10.1212/01.wnl.0000259404.51352.7f

3. Dale RC. Acute disseminated encephalomyelitis. Semin Pediatr Infect Dis. 2003 Apr;14(2):90-5.

DOI: $10.1053 /$ spid.2003.127225

4. Hynson JL, Kornberg AJ, Coleman LT, Shield L, Harvey AS, Kean MJ. Clinical and neuroradiologic features of acute disseminated encephalomyelitis in children. Neurology. 2001;56 (10):1308-12.

5. Anlar B, Basaran C, Kose G, Guven A, Haspolat S, Yakut A, et al. Acute disseminated encephalomyelitis in children: outcome and prognosis. Neuropediatrics. 2003;34(4):194-9.

DOI: $10.4103 / J P N . J P N \_104 \_17$

6. Schwarz S, Mohr A, Knauth M, Wildemann B, StorchHagenlocher B. Acute disseminated encephalomyelitis: a follow-up study of 40 adult patients. Neurology. 2001;56(10): 1313-8.

7. Belopitova L, Guergueltcheva PV, Bojinova V. Definite and suspected multiple sclerosis in children: long-term follow-up and magnetic resonance imaging findings. J Child Neurol. 2001;16(5):317-24. DOI:10.1177/088307380101600503

8. Johnson RT, Griffin DE, Gendelman HE. Postinfectious encephalomyelitis. Semin Neurol. 1985;5:180-90.

9. Murthy SN, Faden HS, Cohen ME, Bakshi R. Acute disseminated encephalomyelitis in children. Pediatrics. 2002;11021-8.

10. Murthy JM. Acute disseminated encephalomyelitis. Neurol India. 2002;50:238-43.

11. Barkhof F, Filippi M, Miller DH, Scheltens P, Campi A, Polman $\mathrm{CH}$, et al. Comparison of MRI criteria at first presentation to predict conversion to clinically definite multiple sclerosis. Brain. 1997;120:2059-69.

12. Noseworthy JH, Hartung HP. Multiple sclerosis and related conditions. In: Neurological Therapeutics. Principles and Practice. $2^{\text {nd }}$ edn. Boca Raton, Flordia, USA: CRC Press, 2006; p. 1225-50.

13. Gupte G, Stonehouse M, Wassmer E, Coad NA, Whitehouse WP. Acute disseminated encephalomyelitis: a review of 18 cases in childhood. J Paediatr Child Health. 2003;39:336-42. DOI: $10.3988 /$ jcn.2016.12.2.245

14. Incecik F, Herguner MO, Altunbasak S. Acute disseminated encephalomyelitis: an evaluation of 15 cases in childhood. Turk J Pediatr. 2013;55:253-9.

15. Van der Knaap MS, Valk J. Acute disseminated encephalomyelitis and acute hemorrhagic encephalomyelitis. In: van der Knaap MS, Valk J, eds. Magnetic Resonance of Myelin, Myelination and Myelin Disorders, $2^{\text {nd }}$ edn. Berlin-Heidelberg: Springer-Verlag, 1995; p. 320-6.

16. Tenembaum S, Fejerman N. Enfermedades des mielinizantes. In: Fejerman N, Fernandez Alvarez E, eds. Neurologíapediátrica, $2^{\text {nd }}$ edn. Buenos Aires: Panamericana, 1997; p. 929-40. (in Spanish) 
17. Tenembaum S, Galicchio S, Grañana N, Ferrea M, Chamoles N, Fejerman N. Multiphasic disseminated encephalomyelitis and multiple sclerosis in children: diagnostic clues. J Neurol Sci. 1997;150 (Suppl):S230.

18. Dale RC, de Sousa C, Chong WK, Cox TCS, Harding B, Neville BG. Acute disseminated encephalomyelitis, multiphasic disseminated encephalomyelitis and multiple sclerosis in children. Brain. 2000;123:2407-22. DOI:10.1007/s00401007-0320-8

19. Hindley DT, Newton RW, Clarke MA, et al. Steroid-responsive relapsing encephalopathy presenting in young children. Neuropediatrics. 1993;24:182.

20. Hartung HP, Grossman RI. ADEM: distinct disease or part of the MS spectrum? Neurology. 2001;56:1257-60.

21. Young NP, Weinshenker BG, Lucchninetti CF. Acute disseminated encephalomyelitis: current understanding and controversies. Semin Neurol 2008;28:84-94.

DOI: $10.1055 / \mathrm{s}-2007-1019130$

22. Leake JAD, Albani S, Kao AS, Senac MO, Billman GF, Nespeca MP, et al. Acute disseminated encepahlomyelitis in childhood: epidemiologic, clinical and laboratory features. Pediatr Infect Dis J. 2004;23:756-64.

23. Tenembaum S, Chamoles N, Fejerman N. Acute disseminated encephalomyelitis: long-term follow-up study of 84 pediatrics patients. Neurology. 2002;59:1224-31.

24. Baum PA, Barkovich AJ, Koch TK, Berg BO. Deep grey matter involvement in children with acute disseminating encephalomyelitis. AJNR Am J Neuroradiol. 1994;15:1275-83.

25. Krupp LB, Banwell B, Tenembaum S, for the International Pediatric MS Study Group. Consensus definitions proposed for pediatric multiple sclerosis and related childhood disorders. Neurology. 2007;68(2):7-12.

DOI:10.1212/01.wnl.0000259422.44235.a8

26. Weber MS, Hemmer B, Cepok S. The role of antibodies in multiple sclerosis. Biochim Biophys Acta. 2011;1812:239-45. DOI: 10.1016/j.bbadis.2010.06.009

27. Wootla B, Denic A, Keegan BM, Jeffrey LW, Astapenko D, Warrington AE, et al. Evidence for the role of B cells and immunoglobulins in the pathogenesis of multiple sclerosis. Neurol Res Int. 2011;2011:780712. DOI: 10.1155/2011/780712

28. Villar LM, Sadaba MC, Roldan E, Masjuan J, GonzálezPorqué P,Villarrubia N, et al. Intrathecal synthesis of oligoclonal IgM against myelin lipids predicts an aggressive disease course in MS. J Clin Invest. 2005;115:187-94. DOI: 10.1172/ JCI200522833

29. Perini P, Ranzato F, Calabrese M, Battistin L, Gallo P. Intrathecal IgM production at clinical onset correlates with a more severe disease course in multiple sclerosis. J Neurol Neurosurg Psychiatry. 2006;77:953-5. DOI: 10.1136/jnnp.2005.086116

30. Fujinami RS, Zurbriggen A. Is Theiler's murine encephalomyelitis virus infection of mice an autoimmune disease? APMIS. 1989;97(1):1-8.

31. Oppenheimer DR. Demyelinating diseases. In: Blackwood W, Corsellis JAN, eds. Greenfield's Neuropathology. $3^{\text {rd }}$ edn. London: Edward Arnold Ltd., 1976; p. 470-99.
32. Greenfield JG, Norman RM. Demyelinating diseases. In: Blackwood W, McMenemey WH, Meyer M, Norman RM, Russell DS, eds. Greenfield's Neuropathology. $2^{\text {nd }}$ edn. London: Arnold; 1971.

33. Turnbull HM, McIntosh J. Encephalomyelitis following vaccination. Br J Exp Pathol. 1926;7:181-222.

34. Malamud N. Sequelae of postmeasles encephalomyelitis: a clinicopathologic study. Arch Neurol Psychiatry. 1939;41: 943-54.

35. Lucchinetti CF, Parisi J, Bruck W. The pathology of multiple sclerosis. Neurol Clin. 2005;23(1):77-105vi. DOI: 10.1016/j. ncl.2004.09.002

36. Dun V, Bale JF Jr, Zimmerman RA, Perdue Z, Bell WE. MRI in children with postinfectious disseminated encephalomyelitis. Magn Reson Imaging. 1986;4:25-32.

37. Caldemeyer KS, Smith RR, Harris TM, Edwards MK. MRI in acute disseminated encephalomyelitis. Neuroradiology. 1994; $36: 216-20$

38. Mikaeloff Y, Adamsbaum C, Husson B, Vallée L, Ponsot G, Confavreux $\mathrm{C}$, et al. MRI prognostic factors for relapse after acute CNS inflammatory demyelination in childhood. Brain. 2004;127(Pt9) :1942-7.DOI: 10.1093/brain/awh218

39. Kesselring J, Miller DH, Robb SA, Kendall BE, Moseley IF, Kingsley D, et al. Acute disseminated encephalomyelitis. MRI findings and the distinction from multiple sclerosis. Brain. 1990;113(Pt 2):291-302.

40. Tintore M, Rovira A, Martinez MJ, Rio J, Diaz-Villoslada P, Brieva L, et al. Isolated demyelinating syndromes: comparison of different MR imaging criteria to predict conversion to clinically definite multiple sclerosis. AJNR Am J Neuroradiol. 2000;21:702-6.

41. O'Connor KC, McLaughlin KA, De Jager PL, Chitnis T, Bettelli $\mathrm{E}, \mathrm{Xu} \mathrm{C}$, et al. Self-antigen tetramers discriminate between myelin autoantibodies to native or denatured protein. Nat Med. 2007;13:211-7. DOI: $10.1038 / \mathrm{nm} 1488$

42. Egg R, Reindl M, Deisenhammer F, Linington C, Berger T. Anti-MOG and anti-MBP antibody subclasses in multiple sclerosis. Mult Scler. 2001;7:285-9. DOI: $10.1177 / 135245850100700503$

43. O'Connor KC, Chitnis T, Griffin DE, Piyasirisilp S, Bar-Or A, Khoury S, et al. Myelin basic protein-reactive autoantibodies in the serum and cerebrospinal fluid of multiple sclerosis patients are characterized by low-affinity interactions. J Neuroimmunol. 2003;136:140-8.

44. Quintana FJ, Farez MF, Viglietta V, Iglesias AH, Merbl Y, Izquierdo $\mathrm{G}$, et al. Antigen microarrays identify unique serum autoantibody signatures in clinical and pathologic subtypes of multiple sclerosis. Proc Natl Acad Sci U S A. 2008;105: 18889-94. DOI: [10.1073/pnas.0806310105]

45. Hedegaard CJ, Chen N, Sellebjerg F, Soelberg Sørensen P, Graham R, Leslie Q, Bendtzen K, et al. Autoantibodies to myelin basic protein (MBP) in healthy individuals and in patients 
with multiple sclerosis: a role in regulating cytokine responses to MBP. Immunology. 2009;128:e451-e461.

DOI: 10.1111/j.1365-2567.2008.02999.x

46. Van Haren K, Tomooka BH, Kidd BA, Banwell B, Bar-Or A, Chitnis $\mathrm{T}$, et al. Serum autoantibodies to myelin peptides distinguish acute disseminated encephalomyelitis from relapsingremitting multiple sclerosis. Mult Scler. 2013 Nov;19(13): 1726-33. DOI: $10.1177 / 1352458513485653$

47. Wender M. Acute disseminated encephalomyelitis (ADEM). J Neuroimmunol. 2011;231:92-9. DOI: 10.1016/j.jneuroim.2010.09.019

48. Rust RS, Dodson W, Prensky A. Classification and outcome of acute disseminated encephalomyelitis. Ann Neurol.1997;42:491.

49. Singh S, Alexander M, Korah IP. Acute disseminated encephalomyelitis: pictorial essay. AJR Am J Roentgenol. 1999;173: 1101-7.

50. Wingerchuk DM. Current evidence and therapeutic strategies in multiple sclerosis. Semin Neurol. 2008;28:56-68. DOI: $10.1055 / \mathrm{s}-2007-1019128$
51. Straub J, Chofflon M, Delavelle J. Early high-dose intravenous methylprednisolone in acute disseminated encephalomyelitis: a successful recovery. Neurology. 1997;49:1145-7.

52. Sakakibara R, Hattori T, Yasuda K, Yamanishi T. Micturitional disturbance in acute disseminated encephalomyelitis (ADEM). J Auton Nerv Syst. 1996;60:200-5.

53. Bašić-Kes V, Kes P, Zavoreo I, Lisak M, Zadro L, Ćorić L, Demarin V. Guidelines for the use of intravenous immunoglobulin in the treatment of neurological diseases. Acta Clin Croat. 2012;51:673-83.

54. Assa A, Watemberg N, Bujanover Y, Lerman-Sagie T. Demyelinative brainstem encephalitis responsive to intravenous immunoglobulin therapy. Pediatrics. 1999;104(2):301-4.

55. Kleinman M, Brunquell P. Acute disseminated encephalomyelitis: response to intravenous immunoglobulin? J Child Neurol. 1995;10:481- 83.

56. Hahn JS, Siegler DJ, Enzmann D. Intravenous gamma globulin therapy in recurrent acute disseminated encephalomyelitis. Neurology. 1996;46:1173-4.

Sažetak

\section{USPJEŠNO LIJEČENJE AKUTNOG DISEMINIRANOG ENCEFALOMIJELITISA (ADEM) PRAVODOBNOM PRIMJENOM IMUNOGLOBULINA - PRIKAZ SLUČAJA I PREGLED LITERATURE}

\section{A. Repić-Buličic, P. Filipović-Grčic, E. Jadrijević, P. Jurinović i M. Titlić}

Akutni diseminirani encefalomijelitis (ADEM) je upalna demijelinizirajuća bolest središnjega živčanog sustava koja obično pogađa djecu i mlade odrasle osobe. Najčešće ima monofazni tijek, iako su zabilježeni i relapsi bolesti. Klinička prezentacija bolesti uključuje encefalopatiju i multifokalne neurološke deficite. Pouzdani kriteriji za dijagnozu ADEM-a nisu utvrđeni i ponekad ga je teško razlikovati od prve atake multiple skleroze, osobito kod odraslih. Dijagnoza ADEM-a temelji se na kliničkim, radiološkim i laboratorijskim nalazima. U liječenju ADEM-a primjenjuju se visoke doze kortikosteroida, plazmafereza i imunoglobulini. Prikazujemo slučaj mlade odrasle bolesnice kod koje je potpun oporavak uslijedio nakon pravodobne primjene visoke doze metilprednizolona i imunoglobulina.

Ključne riječi: Encefalomijelitis, akutni diseminirani; Imunoglobulini; Kortikosteroidi; Metilprednisolon; Prikazi slučaja 